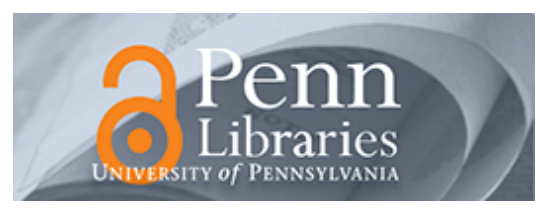

Manuscript Studies

Volume 1

\title{
From Sinai to California: The Trajectory of Greek NT Codex 712 from the UCLA Young Research Library's Special Collections (170/347)
}

Julia Verkholantsev

University of Pennsylvania, juliaver@sas.upenn.edu

Follow this and additional works at: https://repository.upenn.edu/mss_sims

Part of the Medieval Studies Commons

\section{Recommended Citation}

Verkholantsev, Julia (2017) "From Sinai to California: The Trajectory of Greek NT Codex 712 from the UCLA Young Research Library's Special Collections (170/347)," Manuscript Studies: Vol. 1 : Iss. 2 , Article 4.

Available at: https://repository.upenn.edu/mss_sims/vol1/iss2/4

This paper is posted at ScholarlyCommons. https://repository.upenn.edu/mss_sims/vol1/iss2/4

For more information, please contact repository@pobox.upenn.edu. 


\title{
From Sinai to California: The Trajectory of Greek NT Codex 712 from the UCLA Young Research Library's Special Collections (170/347)
}

\author{
Abstract \\ The eleventh- or twelfth-century parchment codex $170 / 347$ is one of the rarities archived in the UCLA \\ Young Research Library Special Collections. It has much to offer to a student of paleography: \\ illuminations, a scribe's colophon, calligraphic minuscule script, later inscriptions and modifications, \\ inserted paper quires, missing folia, study notes, and even a cryptographic table. One of the most \\ fascinating aspects of this New-Testament-turned-lectionary manuscript, however, is its history as a \\ world traveler, for the most part incognito. Although the manuscript's mysterious disappearance from St. \\ Catherine's metochion in Cairo obscured its trajectory, the analysis of its graffiti and the comparison of \\ catalogs' data help reestablish its provenance and narrate its journey beyond the walls of a monastic \\ scriptorium. The resulting travelogue not only tells the story of how Sinai-born MS 170/347 landed in Los \\ Angeles; it offers insight into the fate that befell many other rare books in the height of the nineteenth- \\ century collecting and scholarship rush.
}

\section{Keywords}

manuscript studies, Greek, colophon, New Testament, St. Catherine's Monastery, Mt. Sinai, Konstantine Alexsandrovish Uspenski (1804-1885), Greek paleography, codicology, book theft, University of California Young Research Library, Greek NT Codex 712 


\section{MANUSCRIPT STUDIES}

A Journal of the Schoenberg Institute for Manuscript Studies

VOLUME 1, NUMBER 2

(Fall 2016)

Manuscript Studies (ISSN 2381-5329) is published semiannually

by the University of Pennsylvania Press

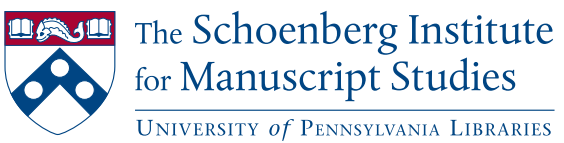




\section{MANUSCRIPT STUDIES}

VOLUME 1, N UMBER 2

(Fall 2016)

\section{ISSN 2381-5329}

Copyright (C) 2016 University of Pennsylvania Libraries and University of Pennsylvania Press. All rights reserved.

Published by the University of Pennsylvania Press, 3905 Spruce Street, Philadelphia, PA 19104.

Printed in the U.S.A. on acid-free paper.

Manuscript Studies brings together scholarship from around the world and across disciplines related to the study of premodern manuscript books and documents, with a special emphasis on the role of digital technologies in advancing manuscript research. Articles for submission should be prepared according to the Chicago Manual of Style, $16^{\text {th }}$ edition, and follow the style guidelines found at http://mss.pennpress.org.

None of the contents of this journal may be reproduced without prior written consent of the University of Pennsylvania Press. Authorization to photocopy is granted by the University of Pennsylvania Press for libraries or other users registered with Copyright Clearance Center (CCC) Transaction Reporting Service, provided that all required fees are verified with CCC and paid directly to CCC, 222 Rosewood Drive, Danvers, MA 01923. This consent does not extend to other kinds of copying for general distribution, for advertising or promotional purposes, for creating new collective works, for database retrieval, or for resale.

\section{SUBSCRIPTION INFORMATION:}

Single issues: $\$ 30$

Print and online subscriptions: Individuals: \$40; Institutions: \$90; Full-time Students: \$30 International subscribers, please add $\$ 18$ per year for shipping.

Online-only subscriptions: Individuals: \$32; Institutions: \$78

Please direct all subscription orders, inquiries, requests for single issues, address changes, and other business communications to Penn Press Journals, 3905 Spruce Street, Philadelphia, PA 19104. Phone: 215-573-1295. Fax: 215-746-3636. Email: journals@pobox.upenn.edu. Prepayment is required. Orders may be charged to MasterCard, Visa, and American Express credit cards. Checks and money orders should be made payable to "University of Pennsylvania Press" and sent to the address printed directly above.

One-year subscriptions are valid January 1 through December 31. Subscriptions received after October 31 in any year become effective the following January 1 . Subscribers joining midyear receive immediately copies of all issues of Manuscript Studies already in print for that year.

Postmaster: send address changes to Penn Press Journals, 3905 Spruce Street, Philadelphia, PA 19104.

Visit Manuscript Studies on the web at mss.pennpress.org. 


\title{
From Sinai to California \\ The Trajectory of Greek NT Codex 712 from the \\ UCLA Young Research Library's Special Collections (170/347)
}

\author{
Julia Verkholantsev \\ University of Pennsylvania
}

Me MANUSCRIPT AND ICONOGRAPHic treasures of the Holy
Monastery of St. Catherine at Mt. Sinai have always been of par-
ticular interest to scholars of early Christian history and Biblical studies. Since the late medieval period, the monastery has attracted both humble pilgrims and adventurous scholars. Despite best efforts of the latter, the strict supervision of St. Catherine's brethren over the library hindered manuscript examination and research for centuries. The monks kept strangers away from their library and tried to mislead visitors, convincing them that there were no valuable manuscripts at St. Catherine's. In the nineteenth century, the intensified textual study of the Bible made the Sinai scriptorium and library a manuscript Mecca for those searching for ancient textual versions. Dedicated learned men and women traveled to Sinai from far away to document and describe as many manuscripts as the Sinaite monks would consent to disclose. The most persistent and resourceful, not to mention unscrupulous, of this adventurous lot tried not only to get access to the valuable manuscripts but to spirit them away for the sake of scholarship and, of course, collecting.

The mystery surrounding St. Catherine's manuscripts was also fueled by the fact that even the monks themselves did not have a clear idea of all the books that their monastery harbored. Things changed in the second 
half of the nineteenth century when several catalogs and descriptions of the monastery's manuscripts were produced and published. ${ }^{1}$ Among the earliest descriptions-although it was not published until much laterwas that compiled by Archimandrite, and later bishop of Chigirin, Porfirii (Uspenskii), the head of the First Russian Ecclesiastical Mission in Jerusalem (1847-1853) and a connoisseur of Greek letters. ${ }^{2}$ A prominent orientalist, Byzantinist, archaeologist, ethnographer, paleographer, art historian, and theologian, Konstantin Aleksandrovich Uspenskii (18041885 ) is particularly known for his adherence to the new historical critical method in his studies of Oriental and Slavic manuscripts and his revision of Mt. Athos's monastic history. In addition to penning scholarly publications, Porfirii kept a diary of his rather extraordinary life and travels. When his autobiographical notes, spanning forty-three years of his life, were published in 1891, they amounted to eight volumes of unique information about his activities in the Orient: Constantinople, Mt. Athos, Palestine, Egypt, Syria, and Asia Minor. ${ }^{3}$ An ardent collector of Greek manuscripts, Porfirii amassed a personal collection of dated samples of writing covering each and every quarter century starting as far back as AD $900 .^{4}$

1 Among the earliest descriptions are those made by Constantine Tischendorf, "Die Bibliothek des Sinaitenklosters zu Kairo," Jabrbücher der Literatur 112 (1845): 30-40; and Tischendorf, “Die Bibliothek des St. Katharinenklosters am Füße des Sinai," Jabrbücher der Literatur 114 (1846): 45-58.

2 Porfirii (Uspenskii) and V. N. Beneshevich, Catalogus codicum manuscriptorum graecorum qui in monasterio Sanctae Catharinae in Monte Sina asservantur, Tomus I: Codices manuscripti notabiliores bibliothecae monasterii Sinaitici ejusque metochii Cabirensis, ab archimandrita Porphyrio (Uspenskio) descripti, ed. V. N. Beneshevich (Hildesheim: G. Olms, 1965 [1911-1917]).

3 Arkhimandrit Porfirii (Uspenskii), Kniga bytiia moego: Dnevniki i avtobiograficheskiia zapiski episkopa Porfiriia Uspenskago, ed. P. A. Syrku, 8 vols. (St. Petersburg: Imp. Akademiia nauk, 1894-1902).

4 “Ценность Порфириевского собрания греческих рукописей заключается преимущественно в его богатстве рукописями определенных лет (датированными). Нет столетия, начиная с 9, ни даже полстолетия, а начиная с середины 10 века, нет четверти столетия, из которой в Порфириевском собрании не было бы датированных образчиков письма.” V. K. Ernshtedt, Spisok datirovannykh grecheskikb rukopisei Porfirievskogo sobraniia (St. Petersburg: V. S. Balashev, 1885), 1. 
During his scholarly expeditions, Porfirii visited St. Catherine's Monastery on Mt. Sinai twice, in 1845 and 1850. In 1861, he spent several months studying manuscripts in the monastery's metochion (dependency) in Cairo, called Juvania. ${ }^{5}$ Porfirii's records are especially valuable as he had documented manuscripts that were already missing by the time later catalogs were compiled. Unfortunately, Porfirii did not live to see the publication of his work. The edition of his catalog was completed by Vladimir Beneshevich (1874-1938), another prominent Russian Byzantinist, paleographer, and specialist in canon law. Beneshevich not only carried out extensive editorial work on Porfirii's notes but also made some important additions and revisions. He traveled to Sinai to verify Porfirii's descriptions and compared them to other catalogs. Alas, several decades after Porfirii's last visit, Beneshevich found that many manuscripts were no longer in the monastic collection. In the introduction to his edition, Beneshevich complains that many manuscripts described by Porfirii had already disappeared from the monastery and he expresses the hope that some of them might be found or rediscovered with the help of Porfirii's detailed information. He was right, and the story that I am going to share on the following pages is about one such manuscript-a New Testament Greek Codex that once belonged to St. Catherine's monastic library and that, after being passed along by a number of owners, found its home at the UCLA Young Research Library's Special Collections Department. ${ }^{6}$

In 1998, as a student in a Greek paleography graduate seminar, I chose as my final project to describe a manuscript from the UCLA Special Collections (170/347), which was then identified as a late twelfth or early thirteenth-century Greek New Testament (ca. 1200). No other information about the provenance or the date of this manuscript was on record. I started with paleographic description.

5 In the account of his first visit in 1845, Porfirii described the most important manuscripts in St. Catherine's monastic library, including the famous Codex Sinaiticus. His description of the latter covers both the 86 leaves that Tischendorf found and left behind and the 260 leaves that he did not.

6 Porfirii and Beneshevich, Catalogus codicum manuscriptorum graecorum, 90-93 (no. 73). 
Manuscript Studies, Vol. 1 [2017], Iss. 2, Art. 4

Verkholantsev, From Sinai to California

\section{A Brief Codicological and Paleographic Description of the Manuscript ${ }^{7}$}

The core of the manuscript is written on parchment (240 folios [15.5 $\mathrm{x}$ $12.7 \mathrm{~cm}$ ], 5 folios missing) in one column, 33 lines, ruling type $44 \mathrm{C} 1$ according to Leroy $^{8}$ (type I 40c according to the Lake system). The handwriting is upright with letters pendent, words mostly separated, traditional ligatures, iota subscript absent, and n-movable never found before a consonant; angular breathing signs, arched circumflex, high and low points, and comma are used; interrogation point is rare. Abbreviations include nomina sacra and the ends of words at the end of a line; kai may appear abbreviated in S-form or K-form (mostly at the bottom), or unabbreviated (fig. 1).

The ornamentation of the codex is fairly minimalistic. Most initials are in purple, except initials on the first page of each gospel, which are gold over purple. There are geometrical ornaments with floral or plant images at the beginning of each book in purple, blue, gold, red, and green colors (fols. 2, 36v, 58v, 92, 128); simple ornaments (gold over purple) at the beginning of each of Pauline Epistles (fols. 160v, 163v, 167, 169, etc.); and an illuminated letter A (gold over purple) on folio 36v. There are four miniatures of the Evangelists: Matthew, Mark, Luke, and John (fols. 1v, 35v, 57v, 91v).

The scribe of the main portion of the codex-one monk Ioannikios copied the four Gospels, the Acts of the Apostles, and the Pauline Epistles, as well as the preface to Acts by the Alexandrine deacon Euthalius (AD 462)

7 A more detailed description of this manuscript, which consists of (1) the history of the codex, (2) the codicological and paleographic description of the writing, paper watermarks, graffiti, inserted notes, and cryptographic table, (3) a table of contents, (4) a transcript of selected Psalm verses, and (5) the collation of the Gospel of Mark, was composed by Julia Verkholantsev (1-3) and Jie Yuan (3-5) in 1999. The description is kept at the UCLA Special Collections along with the manuscript.

8 Julien Leroy, Les types de reglure des manuscrits grecs (Paris: Éditions du Centre national de la recherche scientifique, 1976).

9 It is possible that the same monk Ioannikios also added pericopes to an Evangeliarium that Gardthausen dated to the thirteenth to fourteenth centuries. Victor Emil Gardthausen, Catalogus codicum graecorum sinaiticorum (Oxford: Clarendon, 1886), 53 (no. 255); Marie Vogel and Gardthausen, Die griechischen Schreier des Mittelalters und der Renaissance (Leipzig: Harrassowitz, 1909), 213-14. 


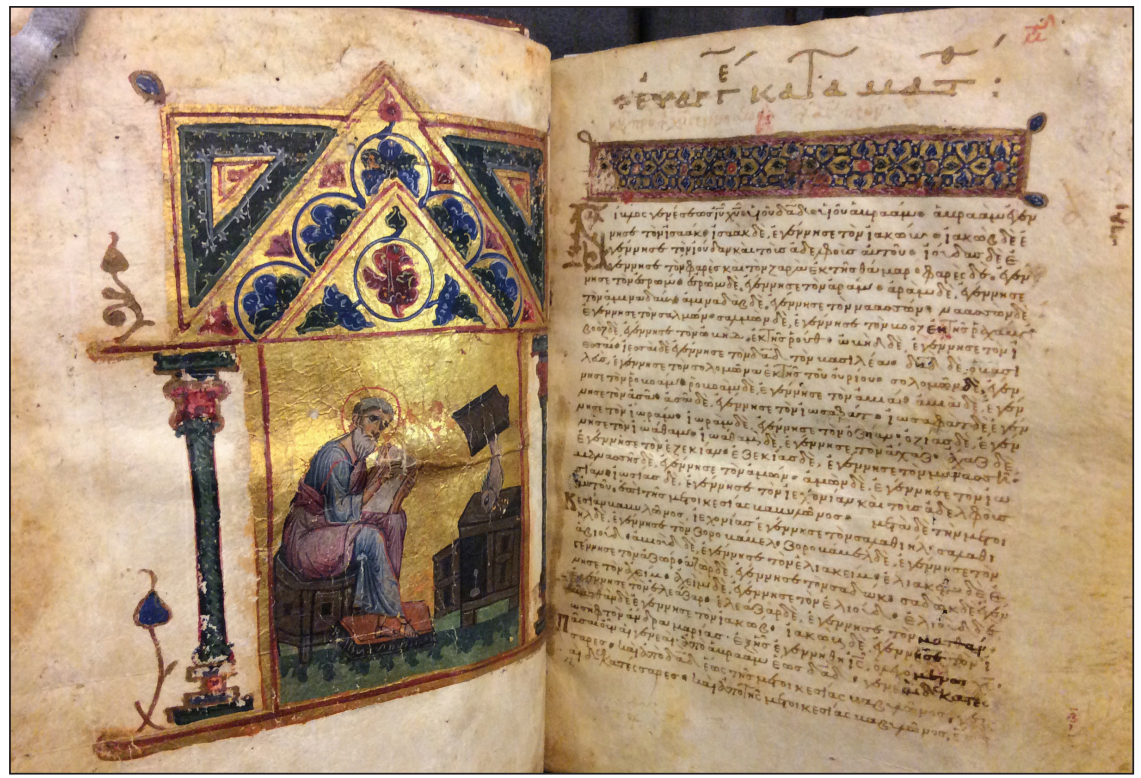

FIGURE 1. Gospel of Matthew. University of California, Los Angeles, Young Research Library, Greek NT Codex 712, fols. 1v and 2. Photographed by the author.

in calligraphic accurate minuscule using brown ink for the main text and purple for initials, chapter titles at the beginning of each book, and the colophon. However, five folios, containing the end of Jude and Euthalius's preface to the Acts of Apostles, are missing from the codex. The codex does not have and never had the Book of Apocalypse: Ioannikios did not consider it a part of the canon, as was not unusual at his time. On the last folio, 239v, he left a colophon (fig. 2):

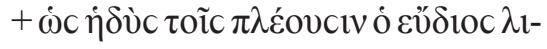

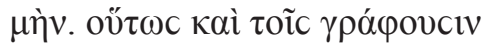

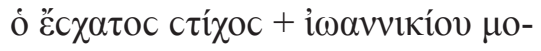
+ vaхo +
As sweet as a quiet harbor is to sailors,

So sweet is a last verse to scribes.

Ioannikios the monk.

Later, someone added hexameter poems celebrating Luke (fol. 57) and John (fol. 90v) in red ink. Another scribe added a lectionary apparatus: he 
Manuscript Studies, Vol. 1 [2017], Iss. 2, Art. 4

Verkholantsev, From Sinai to California

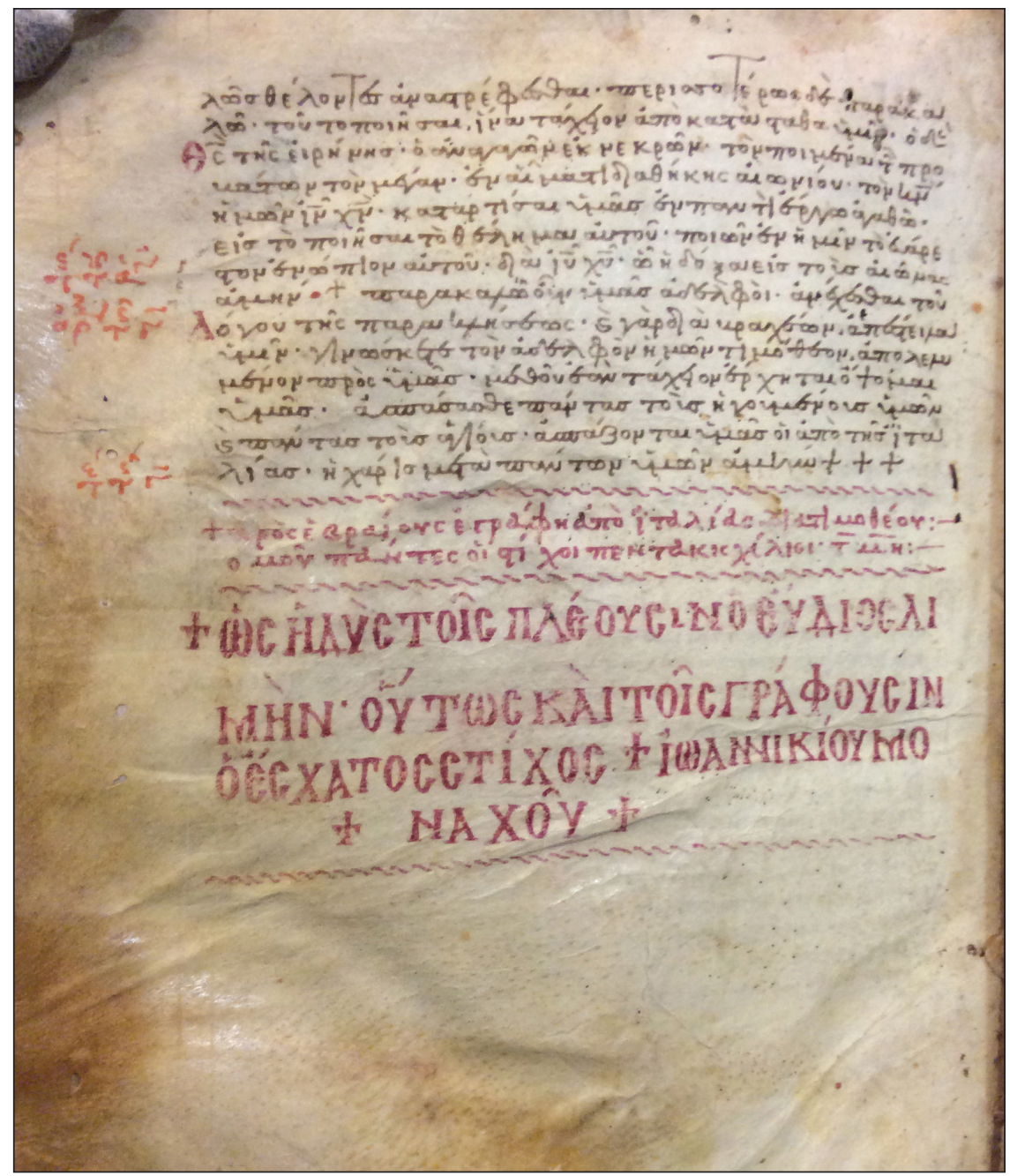

FIGURE 2. Colophon. Greek NT Codex 712, fol. 239v. Photographed by the author.

wrote new chapter titles on the upper and lower margins in red ink over the old tarnished brown titles, added indications of the beginning and the end of daily readings, and added indications of Old Testament quotations. He also amended washed out text in several places and made a few corrections.

A number of insets have been added to the codex. These are two fifteenth-century Italian paper quires with two kinds of watermarks containing readings from Psalms, synaxarium, and menologion (from the time 
when the codex was adapted to the liturgical use) and two quires of new parchment at the beginning and the end (most likely at the time of rebinding in the 1870s).

Having compared the script to the published samples of handwriting of this period, I concluded that the codex could have been written in the eleventh or twelfth century but I did not feel confident enough to narrow down the date.

\section{The Trajectory of the NT Codex 712}

After conducting the preliminary paleographic analysis, outlined above, I began leafing through the classic catalogs of Greek manuscripts, hoping to find a clue that would lead me deeper into the codex's history and verify my paleographic analysis. In the 1963 edition of Aland's Kurzgefasste Liste der griechischen Handscbriften des Neuen Testaments, which I first consulted, two manuscripts show similar physical parameters: a Greek NT that Aland identifies as belonging to the Berkeley Library (Gregory-Aland 712) and a five-folio fragment from the Russian National Library in St. Petersburg. ${ }^{10}$ Remembering that five folios were missing from my codex, I decided to follow this lead and look in Granstrem's catalog of Greek manuscripts of the Russian National Library. ${ }^{11}$ The five folios turned out to be from the collection of Porfirii Uspenskii and of Sinaitic provenance, and, to my absolute delight, they contained the end of Jude and Euthalius's preface to the Acts of Apostles that were missing in the UCLA manuscript. From there it was a short step to Porfirii's catalog and the realization that this manuscript was a world traveler of noble descent: it had come from the library of the Holy Monastery of St. Catherine on Mt. Sinai.

10 In the 1994 edition of Aland's catalog, the Berkeley Library is already changed to the UCLA Library.

11 E. Granstrem, "Katalog grecheskikh rukopisei leningradskikh khranilishch, 1-3," Vizantiiskii vremennik 19 (1961): 239 (Greek 320). 
Manuscript Studies, Vol. 1 [2017], Iss. 2, Art. 4

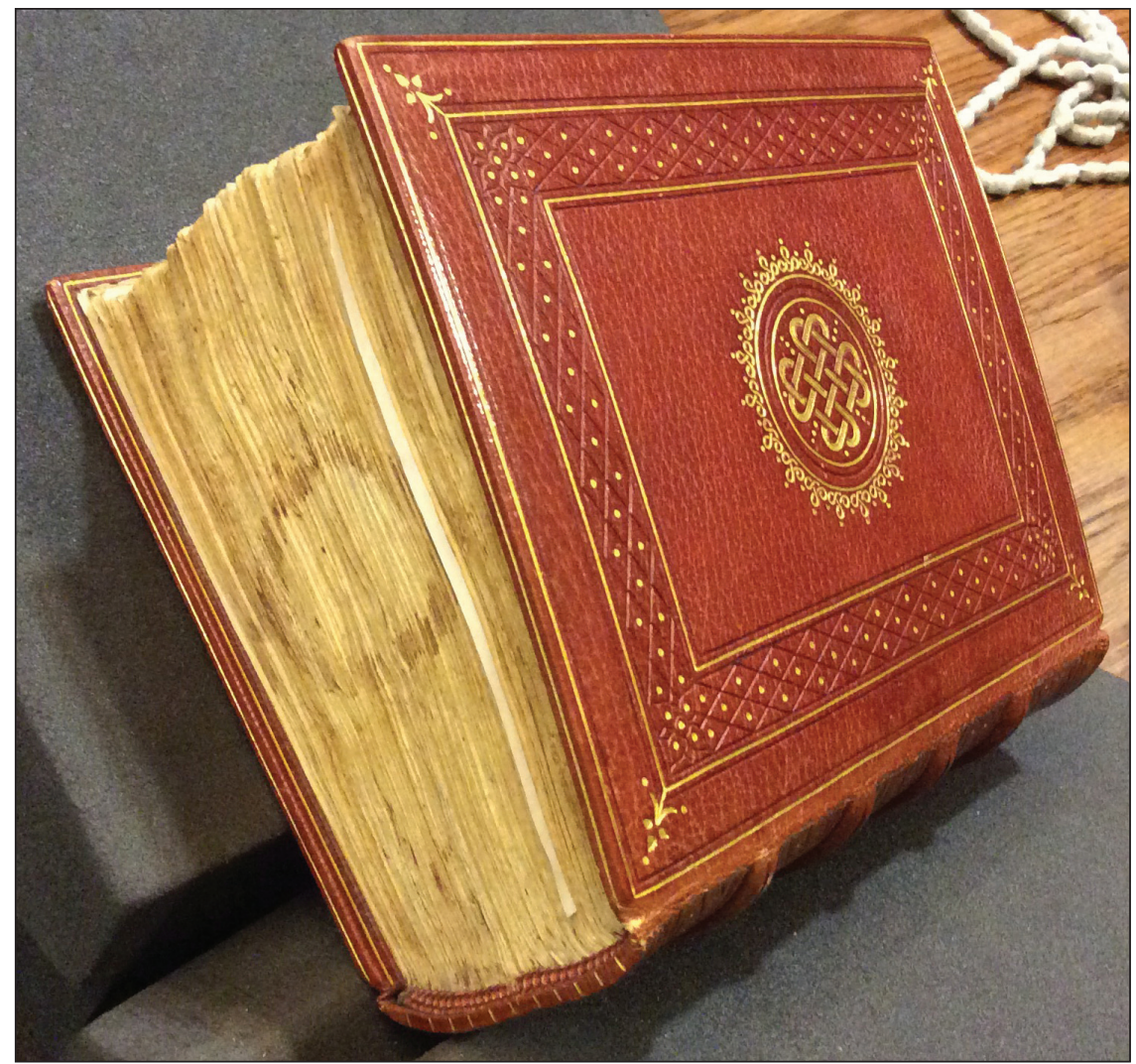

FIGURE 3. Shelfmark from the Holy Monastery of St. Catherine, Mt. Sinai. Greek NT Codex 712. Photographed by the author.

I could have stopped my sleuthing there, but the enigmatic inscriptions and the catalog adventure inspired me to continue the reconstruction of the manuscript's traveling itinerary. From Porfirii's catalog and his diary, I learned that when Porfirii saw this manuscript it was stored in one of the bookcases in the Cairo metochion of St. Catherine's Monastery, called Juvania. A circle-shaped shelfmark $(\mathrm{O})$ is probably an indication of its place there (fig. 3). The monastery possessed many metochia all over the Christian world, but in the nineteenth century the Cairo metocbion was as prominent as the monastery itself: it was the seat of the abbot of St. Catherine's Monastery 
and the archbishop of Sinai, and the majority of the Sinai brethren in fact resided there. In 1861, Porfirii traveled through Egypt and Sinai, and stayed for a couple of months in the Juvanian metochion in order to examine its Greek manuscripts. ${ }^{12}$ As he notes in his diary, he started studying the manuscripts on 10 January and finished his task on 14 February. ${ }^{13}$ It was probably then that Porfirii, a fervent admirer of Greek handwriting andtruth be told - a shameless collector, tore out of the codex a fragment of five folios and added it to his personal collection of Greek handwriting. Shortly before his death, Porfirii sold his whole collection, including the five-folio fragment, to the Imperial Public Library at St. Petersburg (now the Russian National Library), where it remains until present under the call number Greek 320. ${ }^{14}$

Unfortunately, I cannot tell at this time for how long after 1861, when Porfirii last held it in his hands, the codex remained in the possession of St. Catherine's monks. Prior to its disappearance, the codex might have been taken to Sinai for better care: by 1881 the entire Cairo library had been transferred to Sinai, and in 1911 Vladimir Beneshevich reports that among the manuscripts of Juvania there were none left of value since all important manuscripts had been taken to "the mountain."

An important witness to the whereabouts of our codex is a catalog that was compiled in 1870 by Archimandrite Antonin (Kapustin) (1817-1894), also a head of the Russian Ecclesiastical Mission in Jerusalem (1865-1894). Like Porfirii, Antonin kept a diary in which he documented his work and travel, and although his catalog has never been published, his diary gives a good idea about the scope and quality of his project. ${ }^{15}$ During his stay of

12 Porfirii, Kniga bytiia moego, 3:337.

13 Porfirii, Kniga bytiia moego, 3:338-61.

14 Granstrem, "Katalog grecheskikh rukopisei," 239 (Greek 320); Porfirii and Beneshevich, Catalogus Codicum Manuscriptorum Graecorum, 616 (no. 73).

15 Arkhimandrit Antonin (Kapustin), "Iz zapisok sinaiskogo bogomol'tsa," Trudy Kievskoi Dukbovnoi Akademii 1 (1873): 363-34; Antonin, Iz Ierusalima: Stat'i, ocherki, korrespondentsii, 1866-1891, ed. R. B. Butova (Moscow: Indrik, 2010); N. N. Lisovoi, “Arkhimandrit Antonin (Kapustin)—issledovatel' sinaiskikh rukopisei (Po stranitsam dnevnika)," in Tserkov'v istorii Rossii, Sbornik 4, ed. E. V. Beliakova (Moscow: RAN, 2000), 197-225," Ieromonakh Isaiia (Belov), "Issledovaniia arkhimandrita Antonina (Kapustina) na Sinae," Bogoslovskie Trudy 26 
forty days at St. Catherine's, Antonin examined 1310 of the Greek manuscripts and composed what seems to be the most detailed catalogue of St. Catherine's Greek manuscripts at the end of the nineteenth century. Antonin left two copies of his work. Their fate is both remarkable and characteristic of the time. The copy that Antonin took back to Russia never circulated and is now in the Vladimir Beneshevich Collection at the Archive of the Russian Academy of Sciences in St. Petersburg, still awaiting its publication. The copy that Antonin left at the monastery was afterwards lost. However, it was still at St. Catherine's when a German paleographer, Victor Gardthausen of Leipzig University (1843-1925), stayed there in 1880 (also for forty days) while working on his Catalogus codicum graecorum sinaiticorum. It appears that Gardthausen utilized Antonin's work extensively, as a comparison of the two catalogs demonstrates. ${ }^{16}$ Yet he fails to give credit to Antonin and only mentions the work of his predecessor, whose numbering system he admits to having adopted, as that of a nameless "Russian monk." ${ }^{17}$ In his diary, Antonin records his unpleasant surprise at the discovery of Gardthausen's plagiarism. ${ }^{18}$ Antonin's descriptions are not

(1985): 326-33 at 328; Georgi R. Parpulov, "The Greek and Latin Manuscripts of Mount Sinai and the Scholarly World," in St. Catherine's Monastery at Mount Sinai: Its Manuscripts and Their Conservation: Papers Given in Memory of Professor Ihor Ševčenko (London: Saint Catherine Foundation, 2011), 35-42 at 36-37.

16 A. A. Dmitrievskii, Puteshestvie po Vostoku i ego nauchnye rezul'taty (Kiev: KorchakNovitskogo, 1890), 121-48. Dmitrievskii is very critical of Gardthausen's work and gives preference to Antonin's more cautious description.

17 "Numeri, quibus codices notavi, ii sunt quos ipsi prae se ferunt libri, quibusque notati sunt in catalogo manuscripto bibliothecae Sinaiticae, quem monachum Russicum olim fecisse dicunt. Quo libro ut uterer semel per singulam diem mihi concessum est." ("The numbers, by which I have recorded the books, are the same as those in front of the books recorded in the manuscript catalog of the Sinai library, which a monk of Russian origin is said formerly to have created.") Gardthausen, Catalogus codicum graecorum sinaiticorum, viii.

18 A note from 19 April 1887 says: "leafing through a catalog of Sinai manuscripts of one Gardthausen, who used my work without my name, blindly following my established order and giving manuscripts my numbering system, which, according to him, long time ago olim monachum Russicum . . . facisse dicunt.” (“. . . перечитывание Синайского каталога рукописей некоего Gardthausen'a, воспользовавшегося моим трудом безименно, слепо следовавшего установленному мною порядку, и оставившего рукописям данную им мною нумерацию, которую, по его словам, впоследствии, давно-olim monachum Russicum 
comprehensive: he notes the material and the size of manuscripts, the number of leaves and lines, main content, ornament and illuminations, if any, and the names of scribes, if known. But the information that Antonin provides is sufficient to conclude that no description in his catalog corresponds to that of the UCLA Greek NT codex 712. This means that by 1870 our manuscript had already been missing from the library at St. Catherine's. ${ }^{19}$ It is even possible that it never made it to "the mountain" and went missing during the transfer of manuscripts from the Cairo metochion.

Back to the manuscript inscriptions, a hardly legible pencil note on fol. 3 of the new parchment inset lead me to the manuscript's next sojourn: "Quaritch considered this manuscript the gem of bis collection of Greek manuscripts." ${ }^{20}$ Checking a number of catalogs of the prominent London antiquarian bookseller Bernard Quaritch revealed our manuscript to have been listed for sale in $A$ General Catalogue of Books for the year 1874. By then it had acquired a new red-brown Morocco leather binding ornamented with gold from "Francis Bedford," and it was offered for the price of $£ 200$. $^{21}$

In 1876 the manuscript was acquired for $£ 120$ by Alexander Peckover (1830-1919), the first and last Baron Peckover of Wisbech, banker, philanthropist, and collector of ancient manuscripts. ${ }^{22}$ His coat of arms is featured on a bookplate on fol. 1v of the new parchment inset (fig. 4). An inscription on fol. $4 \mathrm{v}$ made in black ink also indicates Peckover's name and refers to F.

... facisse dicunt.") L. A. Gerd, “Arkhimandrit Antonin Kapustin i ego nauchnaia deiatel'nost' (po materialam peterburgskikh arkhivov)," in Rukopisnoe nasledie russkikb vizantinistov $v$ arkbivakb Sankt-Peterburga, ed. I. P. Medvedev (St. Petersburg: Dmitry Bulanin, 1999), 8-35 at 32. 19 Arkhimandrit Antonin (Kapustin), "Katalog grecheskikh rukopisei monastyria sv. Ekateriny na Sinae," Archive of the Russian Academy of Sciences in St. Petersburg (PFA RAN), Vladimir Beneshevich Collection 192, file 71. I wish to thank Mila Nazyrova, Anna Mikhailova, Dimitris Yalamas and Panagiotis Agapitos for their help with getting access to this catalog and verifying this information. All mistakes are mine alone.

20 Notes in English, written in pencil on fols. 2-4r.

21 A General Catalogue of Books, Offered to the Public at the Affixed Prices (London: Quaritch, 1874), 2.

22 Caspar René Gregory, Textkritik des Neuen Testaments (Leipzig: Hinrichs, 1908), 215. Gregory saw the manuscript in 1883 and mentions Alexander Peckover as the owner. In 1894, Scrivener mentions his sister, Algerina Peckover (1841-1927), as the owner. 
H. A. Scrivener's catalogue of Greek manuscripts in his Plain Introduction to the Criticism of the New Testament (fig. 5). ${ }^{23}$

Codex. Burgon \& Scrivener Gospel Acts Paul

Peckover $560222 \quad 228$

An inscription on the left upper corner of fol. 1v (fig. 4) bears a sign of sale at a Sotheby's auction, which most likely took place on 4 April 1949:24

\section{Sothebys (Maggs) \\ $£ 600+60=£ 660$ Isaac Foot}

At this sale, Maggs Bros. book dealers purchased the manuscript on commission for Isaac Foot of Callington (1880-1960), a British politician and solicitor and a book collector. On the bottom of the same folio, a black and white bookplate (a person is sitting in a chair and reading a book) with the name Isaac Foot is attached with glue (fig. 5). The codex remained until 1962 in Foot's collection when, after Foot's death, it was acquired by the University of California. Unfortunately, the first edition of Aland's catalog inaccurately places it in the Berkeley Library (and not UCLA), probably due to a complicated process of distribution of the Foot collection among the UC libraries, which obscured the path of this manuscript. ${ }^{25}$ By the time it arrived at UCLA it had lost its association with the 1963 edition of Aland's catalog and any other reference material in general. When I started working

23 Frederick Henry Ambrose Scrivener, A Plain Introduction to the Criticism of the New Testament for the Use of Biblical Students, ed. Edward Miller (4th ed.; London: Bell, 1894). Dean Burgon published in 1873 in The Guardian several articles with suggestions and corrections for the second edition of Scrivener.

24 Catalog (London: Sotheby's, 1949), 23 (no. 198).

25 Kurt Aland, Kurzgefasste Liste der griechischen Handschriften des Neuen Testments (Berlin: de Gruyter, 1963), 99; T. G. Grieder, The Isaac Foot Library: Classified Lists of the Collections Showing Location in the Libraries of the University of California (Santa Barbara: University of California, Santa Barbara, 1963), 6. 
Verkholantsev: From Sinai to California

228 Journal for Manuscript Studies

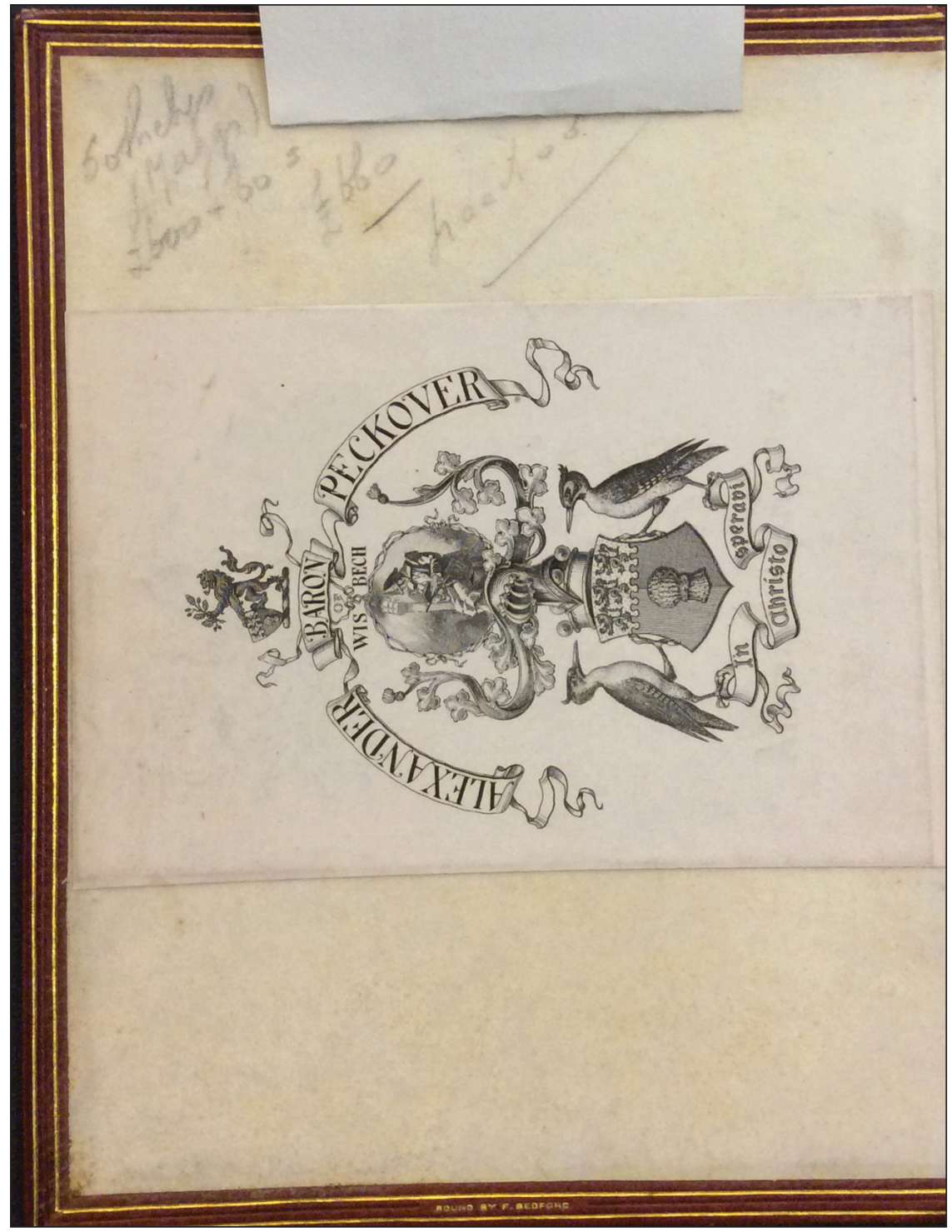

FIGURE 4. Alexander Peckover's book plate and Sotheby's inscription. Greek NT Codex 712 , fol. $1 \mathrm{v}$ of new parchment inset. Photographed by the author. 
Manuscript Studies, Vol. 1 [2017], Iss. 2, Art. 4

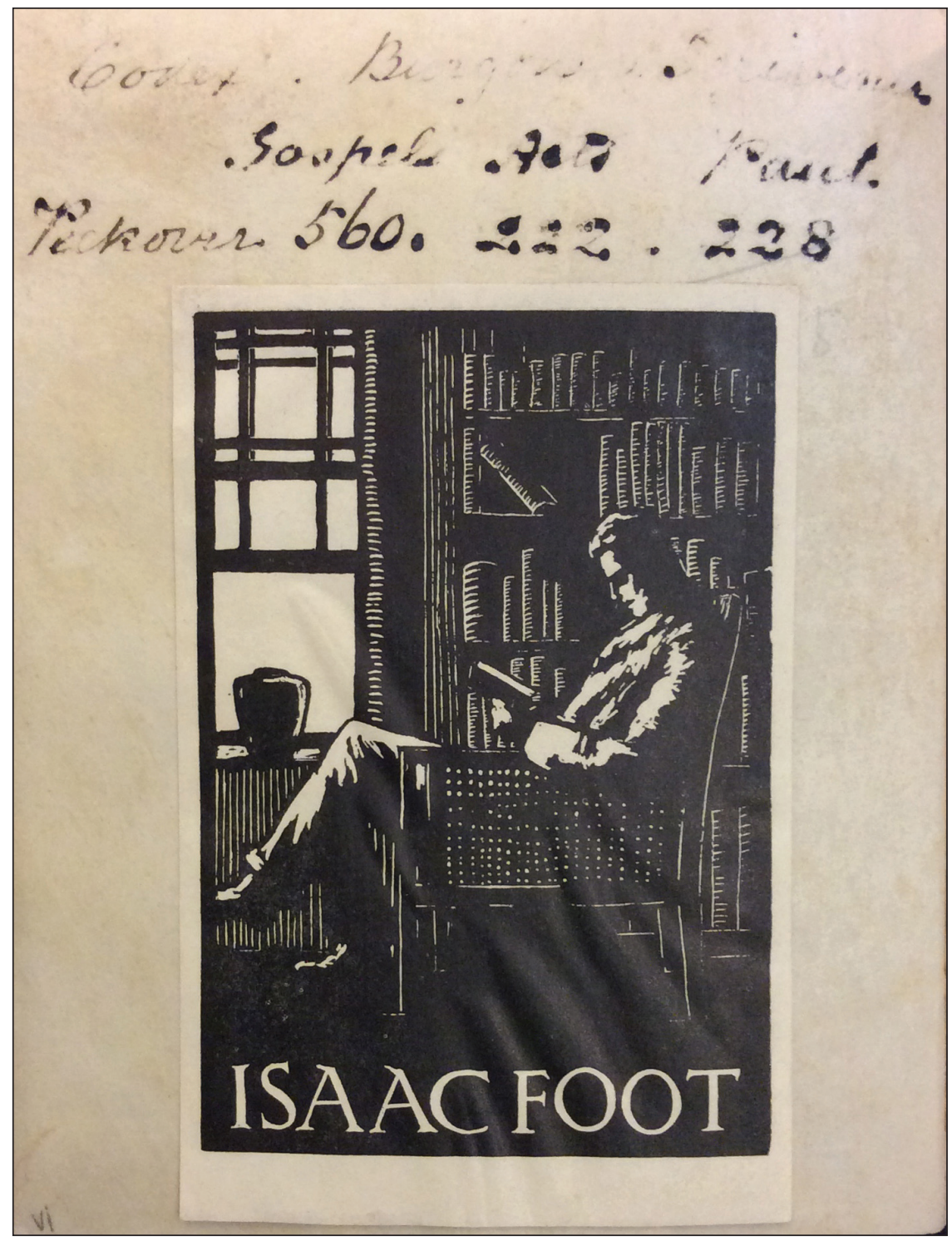

FIGURE 5. Isaac Foot's book plate and Scrivener's inscription, Greek NT Codex 712, flyleaf. Photographed by the author. 
on the description, virtually nothing was known to the UCLA manuscript curators about this manuscript.

What is remarkable is that the knowledge of its Sinai provenance was lost at the very beginning of its journey. The description in the Quaritch catalog, otherwise so detailed, makes no reference to St. Catherine's. This raises suspicion about how the manuscript got to London. Was it stolen from Cairo or Sinai? Was it sold by a mischievous monk? This link being broken, the manuscript's connection to the five-folio fragment in Porfirii's collection (Greek 320) also temporarily vanished. On 30 September 1903, Caspar Gregory examined the five-folio fragment in St. Petersburg and failed to associate it with the NT codex that he had examined back on 22 June 1883. He even dated them differently: the codex to the eleventh century and the St. Petersburg five-folio fragment to the thirteenth century (after Porfirii's own dating). ${ }^{26}$ In the fourth edition of his catalog (1894), Scrivener does not mention the five-folio fragment at all and dates the codex to the eleventh century. ${ }^{27}$ In 1911 , Beneshevich saw the link between the codex and the five-folio fragment in Porfirii's notes but he was unable to find the codex itself. In his edition of Porfirii's catalogue, he dated both to the eleventh or twelfth centuries on the basis of the five-folio fragment (Greek 320). ${ }^{28}$

Thus, the most interesting question is how did the manuscript disappear from St. Catherine's, which happened sometime between 1861 (when Uspenskii described it) and 1870 (when Antonin compiled his catalog)? At that time not many people from the West were allowed to visit and examine libraries at St. Catherine's monastery and its metochion in Cairo. In 1858, the German scholar Constantin von Tischendorf (1815-1874), through the assistance of the Russian government, received special permission from the Patriarch of Constantinople and the Archbishop of Sinai to take from the Eastern monasteries manuscripts and fragments that were no longer in use

26 Gregory, Textkritik des Neuen Testaments, 215 (no. 712), 1197 (no. 2164).

27 Scrivener, A Plain Introduction, 1:225 (no. 560).

28 Otchet Imperatorskoi Publichnoi Biblioteki za 1883 god (Report of the Imperial Public Library for 1883) (St. Petersburg: Balasheva, 1885), 129 (no. 63). Porfirii and Beneshevich, Catalogus Codicum Manuscriptorum Graecorum, 90. 
or did not serve as a special decoration. In return, he promised to bring to the Russian government manuscripts in different languages important for study, and indeed the Public Library in St. Petersburg purchased many manuscripts from him when he came back from his expedition. ${ }^{29} \mathrm{He}$ also succeeded in taking one of the oldest and most valuable manuscripts from the monastery, the famous Codex Sinaiticus, and presenting it to the Russian Emperor, first as a loan, but eventually, as it turned out, forever. ${ }^{30}$ Like many other scholars, Tischendorf regarded the Sinai monks as unworthy of keeping valuable ancient manuscripts because he was convinced that the monks did not take proper care of them. This event was widely discussed in the Orthodox circles, and Tischendorf was censored by many. Incidentally, Porfirii Uspenskii, himself not quite innocent in pocketing manuscript relics, took Tischendorf's side. In his diary from 28 November 1860, Porfirii relates a conversation with the Patriarch Kallinikos of Alexandria in which he tried to justify the relocation of the Codex Sinaiticus to Russia: "From your library this ancient treasure can disappear, or get into the English, French, or German hands, but in our possession it will be safe. Our Catholic Church is one big home." 31 Ironically, this codex did end up in the British Museum in 1933, when it was sold by the Soviet government for $£ 100,000$. However, whether or not guilty of the theft of the Codex Sinaiticus,

29 Edouard de Muralt, Catalogue des manuscrits grecs de la Bibliothèque impériale publique (St. Petersburg: Imperial Academy of Sciences, 1864).

30 Codex Sinaiticus, a manuscript of the Christian Bible written in the middle of the fourth century, is one of the most important documents for biblical textual scholarship because it contains the earliest complete text of the New Testament. The New Testament is in the vernacular language (koine) and the Old Testament in the version known as the Septuagint that was adopted by early Greek-speaking Christians. The texts of both the Septuagint and the New Testament are heavily annotated by a number of readers. For more information on the Codex Sinaiticus, see David C. Parker, Codex Sinaiticus: The Story of the World's Oldest Bible (London: British Library, 2010); Scot McKendrick, David Parker, Amy Myshrall, and Cillian O'Hogan, eds., Codex Sinaiticus: New Perspectives on the Ancient Biblical Manuscript (Peabody, MA: Hendrickson, 2015).

31 "У вас старина эта может исчезнуть и попасть в руки англичан, французов, немцев, а у нас она будеть сохранна. Наша католическая церковь есть один большой дом." Porfirii, Kniga bytiia moego, 284. 
Tischendorf had no hand in stealing our manuscript since he did not travel to Sinai or Cairo after 1861.

But Tischendorf was not the only one pursuing Sinaitic treasures. Despite the vigilance of the monks, some lucky and/or thieving individuals succeeded in exporting manuscripts from Sinai to the West. In 1865, a Professor-Egyptologist Heinrich Brugsch, then consul in Cairo, and in 1871 his colleague Georg Ebers, traveled to St. Catherine's on a manuscript hunt and tried to purchase some Greek manuscripts from the Sinai monks, reportedly without success. ${ }^{32}$ Yet in 1866 the Berlin Library recorded a substantial acquisition of manuscripts from Sinai brought by Brugsch. ${ }^{33}$ A note in the catalog description of an eighth- or ninth-century Greek lectionary manuscript fragment, no. 267 (as well as a number of other manuscripts), says: "These leaves have come to the library from the Sinai Monastery through the mediation of Consul Brugsch." ${ }^{4}$ Yet, in his travelogue published in 1866, Brugsch again declares that he was unsuccessful in taking hold of any manuscripts during his visit to the monastery:

While Tischendorf and others were so lucky in their acquisition of manuscripts for European libraries from this treasure house, now the Sinaites — as it seems at higher orders — approach the trade of manuscripts, even single leaves, with great caution, and all my

32 Vladimir Beneshevich, Les Manuscrits Grecs du Mont Sinaï et le monde savant de l'Europe depuis le XVIIe siècle jusqu'à 1927 (Athenes: Byzantinisch-neugriechischen Jahrbücher, 1937), 53; Georg Ebers, Durch Gosen zum Sinai: Aus dem Wanderbuche und der Bibliothek (Leipzig: Engelmann, 1881), 260-321.

33 "Hervorzuheben sind die grösseren Erwerbungen der von Brugsch auf dem Sinai gesammelten, 1866 in die Bibliothek aufgenommenen Handschriften." ("Noteworthy are major acquisitions of manuscripts collected by Brugsch on Sinai, recorded in the library in 1866.") Carl de Boor, Verzeichniss der griechischen Handschriften der Königlichen Bibliothek zu Berlin, vol. 2 (Berlin: Asher \& Co, 1897), 121.

34 "Die Blätter sind im Mai 1866 durch Vermittelung des damaligen Consuls Brugsch in Cairo aus einem Kloster des Sinai in die Bibliothek gekommen." ("The leaves came to the library from the monastery of Sinai in May 1866 through the mediation of the former Consul Brugsch in Cairo.") De Boor, Verzeichniss der griechischen Handschriften, 139. 


\section{Manuscript Studies, Vol. 1 [2017], Iss. 2, Art. 4}

efforts to acquire some manuscripts suffered complete failure due to the determination of the monks not to give away anything. ${ }^{35}$

Only a privileged guest or an insider could have been given access to the manuscript library, which, according to Brugsch, was closely guarded and locked at all times. In another account, Brugsch elaborates on the spiritual attachment of the Sinatic monks to their manuscripts: "Some of these manuscripts can easily date from the fourth or fifth century; but attempts to buy them from the monks succeed neither by persuasion nor by gold. 'Sir,' says the Prior of the monastery, 'these books are written by our brothers, who rest for centuries in the earth; they force us solemnly at the end of each manuscript never to give away any of these devout offerings for the sake of the salvation of our souls." ${ }^{36}$ Their sentiments are easily understandable: the infamous Tischendorf's deceit taught monks to be particularly suspicious of scholars. ${ }^{37}$

It is possible that further archival investigation will help determine exactly when and who acquired, stole, purchased, or received our manuscript as a gift between 1861 and 1870. This account of one student's odyssey through old catalogs and diaries highlights the fate that befell the UCLA

35 "Während Tischendorf und andere so glucklich waren, aus dieser Fundgrube einige Manuscripte für die europäischen Bibliotheken so erwerben, so ist man jetzt auf dem Sinai, wie es scheint auf höheren Besehl, sehr vorsichtig mit der Beräuszerung von Handschriften, selbst von einzelnen Blättern, und alle meine Bemühungen einzelnes zu erwerben, scheiterten vollkommen an der Entschiedenheit der Mönche irgend etwas zu überlassen." Heinrich Brugsch, Wanderung nach den Türkis-Minen und der Sinai-Halbinsel (Leipzig: Hinrichs, 1866), 42-43.

36 "Einige dieser Manuscripte koennen leicht ein Alter von vier bis fuenf Jahrhunderten haben; sie den Moenchen abzukaufen, gelingt weder durch Ueberredung, noch Gold. 'Herr,' sagt der Prior des Klosters, 'diese Buecher sind von Bruedern geschrieben, welche nun schon Jahrhunderte im Erdenschosse ruhen. Sie haben uns am Ende jeder Handschrift das feierliche Geluebde auferlegt, keines dieser frommen Vermaechtnisse, bei Verlust unseres Seelenheiles, in irgend einer Weise zu veraeussern." Heinrich Brugsch, Aus dem Orient, 2 vols. (Berlin: W. Grosse, 1864), 1:89.

37 Ihor Ševčenko, "New Documents on Constantine Tischendorf and the Codex Sinaiticus," in Ševčenko, Byzantium and the Slavs in Letters and Culture (Cambridge, MA: Harvard Ukrainian Research Institute, 1991). 
234 | Journal for Manuscript Studies

Greek NT manuscript codex 712 and many other manuscripts and rare books during the height of the nineteenth-century rush to collect and study. Although these written treasures were taken from their homes and dispersed around the world, their pages retain marks of their itineraries, and their progress has been documented by the labors of assiduous and philanthropic scholars. It is to them that I devote this essay. 